\title{
Progress in the eradication of the feral cat (Felis catus) and recovery of the native fauna on Socorro Island, Revillagigedo Archipelago, Mexico
}

\author{
Antonio Ortiz-Alcaraz ${ }^{1,2 *}$, Alfonso Aguirre-Muñoz ${ }^{1}$, Gustavo Arnaud ${ }^{2}$, Patricia Galina-Tessaro ${ }^{2}$ \\ Evaristo Rojas-Mayoral ${ }^{1}$, Federico Méndez-Sánchez ${ }^{1}$ and Alfredo Ortega-Rubio² \\ ${ }^{1}$ Grupo de Ecología y Conservación de Islas, A. C. Moctezuma 836, CP. 22800, Ensenada. Baja California, Mexico. Email: antonio. \\ ortiz@islas.org.mx (AOA), alfonso.aguirre@islas.org.mx (AAM), evaristo.rojas@islas.org.mx (ERM), federico.mendez@islas.org.mx \\ (FMS). \\ ${ }^{2}$ Centro de Investigaciones Biológicas del Noroeste, S. C. Instituto Politécnico Nacional 195, CP. 23096, La Paz. Baja California Sur, \\ México. Email: garnaud04@cibnor.mx (GA), pgalina04@cibnor.mx (PGT), aortega@cibnor.mx (AOR). \\ ${ }^{*}$ Corresponding author
}

Socorro Island, in the Revillagigedo Archipelago, has the highest number of endemisms of any Mexican island. It provides habitat for 117 vascular plants, $26 \%$ of which are endemic to the island. Also endemic to the island are one reptile and eight terrestrial bird species. However, the local ecosystem has been heavily degraded by exotic mammals over the past 140 years. The feral sheep (Ovis aries) has contributed to a $30 \%$ loss in habitat based on the island's surface area. Another serious threat is the feral cat (Felis catus), which has severely impacted the island's bird communities and the endemic Socorro tree lizard (Urosaurus auriculatus). Together, feral sheep and cats are responsible for the extinction in the wild of the Socorro dove (Zenaida graysoni) and the Socorro Elf Owl (Micrathene whitneyi graysoni), and pose a serious threat for other vulnerable species, such as the Townsend's shearwater (Puffinus auricularis). The feral sheep was completely eradicated in 2012 , which resulted in a rapid and remarkable recovery of the local vegetation cover. The eradication of the feral cat has been a complex issue to undertake due to the large size and topographical complexity of Socorro Island. In 2011 Grupo de Ecología y Conservacion de Islas, A. C. (GECI) started a feral cat control program, which scaled up into an eradication campaign. Here we report on the progress of the eradication campaign between 2011 and 2015, and provide a first assessment of the recovery of the native fauna. Beginning in 2011, camera traps were used to estimate cat abundance. Leg-hold and lethal traps were used to capture feral cats, some of them mounted with telemetry devices that alerted when traps were activated. Native vertebrates were monitored to confirm the positive effects derived from cat control efforts. By July 2015,413 cats were dispatched using soft leg-hold and lethal traps, with a combined effort of 22,706 trap-nights. To date (mid-2016), cat abundance has decreased significantly, with cats being completely absent for several years in different areas of the island. The abundance of the endemic Socorro Island tree lizard and terrestrial birds has increased thanks to significant progress. Completing this important conservation action requires an increase in trapping efforts and the use of detection dogs, combined with night hunting. We estimate that the eradication of the feral cat will be completed by early 2017 , after which the absence confirmation phase will begin.

Isla Socorro, Archipiélago de Revillagigedo, es la isla con el mayor nivel de endemismos en México. Es hábitat de 117 especies de plantas vasculares, 26 \% de las cuales son endémicas. Alberga una especie de reptil y ocho especies de aves terrestres endémicas. Sin embargo, este ecosistema insular ha sido fuertemente degradado debido a la presencia de mamíferos exóticos por más de 140 años. El borrego feral (Ovis aries) causó la destrucción del hábitat en 30 \% de la superficie de la isla. Otra seria amenaza es la presencia del gato feral (Felis catus), el cual ha tenido un severo impacto negativo por depredación sobre la avifauna nativa y la lagartija azul (Urosaurus auriculatus), endémica de Isla Socorro. Juntos, el gato y el borrego feral, son responsables de la extinción en el medio silvestre de la paloma de Socorro (Zenaida graysoni) y del tecolote de Socorro (Micrathene whitneyi graysoni), además de ser una seria amenaza para otras especies vulnerables, destacando la pardela de Revillagigedo (Puffinus auricularis). La erradicación del borrego feral se completó en 2012, lo que resultó en una rápida y notable recuperación de la cobertura vegetal. La erradicación del gato feral ha sido un reto mayor dado al gran tamaño y la complejidad topográfica de Isla Socorro. En 2011, el Grupo de Ecología y Conservación de Islas, A. C. (GECl) inició un programa de control de gato feral que poco tiempo después se convirtió en una campaña de erradicación. En este trabajo reportamos los avances de la erradicación entre los años 2011 y 2015 , y ofrecemos una primera evaluación de la recuperación de la fauna nativa. Mediante el uso de cámaras trampa (a partir de 2011) se estimó la abundancia del gato feral. Para la captura de los gatos se emplearon trampas de cepo y letales, algunas equipadas con equipos de telemetría que alertan cuando éstas han sido activadas. Se realizaron monitoreos de vertebrados nativos a fin de confirmar los efectos positivos de los esfuerzos de control del gato feral. Hasta julio de 2015 se sacrificaron 413 gatos con trampas de cepo de cojinete y letales, con un esfuerzo acumulado de 22,706 trampas-noche. A la fecha (mediados de 2016), la abundancia de gatos ha disminuido aún más, y ya están completamente ausentes de varias zonas de la isla. La abundancia de la lagartija azul de Isla Socorro y las aves terrestres endémicas ha incrementado gracias a los avances en la erradicación del gato. A la fecha se ha logrado un avance significativo en la erradicación del gato feral. Para completar esta acción prioritaria de conservación, es necesario incrementar el esfuerzo de trampeo, así como el uso de perros de muestra combinado con cacería nocturna. Estimamos que la erradicación de gato feral se completará a principios de 2017, cuando iniciará la fase de confirmación de ausencia.

Key words: cat; conservation; eradication; Felis catus; Revillagigedo Archipelago; Socorro Island.

(c) 2016 Asociación Mexicana de Mastozoología, www.mastozoologiamexicana.org 


\section{Introduction}

The islands of Mexico are recognized worldwide for their high biodiversity, since these host a large number of endemic species (Aguirre-Muñoz et al. 2005; 2011; 2016). However, many islands in Mexico and around the world have experienced severe impacts resulting from human activities (Johnson and Stattersfield 1990; Chapuis et al. 1994; Algar et al. 2004; Bonnaud et al. 2011). Approximately $75 \%$ of animal extinctions have occurred in islands, mainly because of introduced species (Ebenhard 1988; Diamond 1989; Groombridge 1992). Alien species are the main cause of biodiversity loss and ecological imbalance in many environments (Chapuis et al. 1994; Moro 1997; Bonnaud et al. 2011). In Mexico, cats were introduced into at least 34 islands, causing serious impacts on the native fauna and contributing to the disappearance of seabirds and the confirmed extinction of 17 species of birds and mammals in Mexican islands (Aguirre-Muñoz et al. 2011; 2016). In Guadalupe Island, for example, the feral cat has been responsible for the extinction of endemic species such as the birds Guadalupe Bewick's wren (Thyromanes bewickii brevicauda) and the Guadalupe towhee (Pipilo maculatus consobrinus), in addition to posing a risk for seabird populations, including the likely extinction of the Guadalupe storm petrel (Hernández-Montoya et al. 2014).

In the case of Socorro Island, the feral sheep (Ovis aries), the feral cat (Felis catus) and the domestic mouse (Mus musculus) have caused significant negative impacts on the ecosystem. The feral sheep was responsible for soil erosion, loss of vegetation cover and habitat modification (Levin and Moran 1989; Alvarez-Cárdenas et al. 1994; León de la Luz et al. 1994; MayaDelgado et al. 1994; Brattstrom 2015), which led to negative impacts on the native fauna (Martínez-Gomez et al. 2001). For its part, the feral cat, introduced into the island in the 1950s, poses a serious threat for the local vertebrate populations. Predation by cats threatens the persistence of native species, particularly those of small population size, such as the Socorro tree lizard (Urosaurus auriculatus; Arnaud et al. 1993; 1994). Likewise, feral cats contributed to the extinction in the wild of the Socorro dove (Zenaida graysoni) and the Socorro elf owl (Micrathene whitneyi graysoni), and has also led to other species being listed as endangered of extinction, as is the case of the Socorro mockingbird (Mimus graysoni) and the Townsend's shearwater (Puffinus auricularis; Martinez-Gomez and Jacobsen 2004).

Achieving the recovery of both the habitat and native species requires the eradication of the introduced species (Veitch and Clout 2002; Aguirre-Muñoz et al. 2005; Veitch et al. 2011; Jones et al. 2016). Given the threats that Socorro Island currently faces, from 2009 to 2012 the Mexican environmental organization named Grupo de Ecología y Conservación de Islas, A. C. (GECl) undertook the eradication of the feral sheep that has led to a remarkable homeostatic environmental recovery (Ortiz-Alcaraz et al. 2016a; 2016b). The eradication of the feral cat represented another serious challenge, since Socorro is a large and complex island, and little baseline information was available on the distribution and abundance of this species (Arnaud et al. 1994). Fortunately, technologies have been developed in islands in Mexico and worldwide for the eradication of feline predators (Bester et al.2002; Wood et al. 2002; Algar et al. 2010; Aguirre-Muñoz et al. 2011; Luna-Mendoza et al. 2011; Parkes et al. 2014). For the successful implementation of an eradication campaign of this type, is essential to determine the ecology of the species, assess the impact of the applied methods on the native fauna, and to develop an executive eradication plan (Veitch 1989; Arnaud et al. 1994; Donlan et al. 2003; Dowding et al. 2009). Given the imminent risk that predation by cats posses to the island's endemic species, there was an urgent need to execute a control program that would provide information about the biology of this predator. Thus, an intensive monitoring program of feral cats in Socorro Island was launched in 2000, aimed at achieving its eradication. This work describes the methods used, the progress achieved between 2011 and 2015, and the preliminary results of the recovery of native fauna after the implementation of erradication efforts.

\section{Materials and Methods}

Study area. Socorro Island is a federal territory that belongs to the Revillagigedo Archipelago. It is located $460 \mathrm{~km}$ south of Cabo San Lucas, Baja California Sur, and 694 km west of Manzanillo, Colima ( $18.7833^{\circ} \mathrm{N},-110.9666^{\circ} \mathrm{W}$, Figure 1). It comprises an area of $132 \mathrm{~km}^{2}$ with a maximum altitude of $1,050 \mathrm{~m}$. The island is home to 117 species of vascular plants, 30 of which are endemic (León de la Luz et al. 1994). The fauna of Socorro Island includes 103 species of terrestrial birds, eight species of which are endemic, seabirds and one endemic reptile, the Socorro Island tree lizard, endemic to the island. In addition, Socorro Island is the only nesting site of the Townsend's shearwater, a seabird endemic to the archipelago. The island is permanently inhabited by 50 soldiers of Mexico's Secretariat of the Navy (SEMAR, for its acronym in Spanish), which has a Naval Sector in the southeastern end of the island (CONANP 2004).

Feral cat monitoring and control. The relative abundance of cats was estimated using camera traps. During April-May and November of 2011 to 2015 (two annual monitoring events, one for each season), eight transects with camera traps were set (Bushnell Trophy cam HD Agressor). Each transect ran across $3 \mathrm{~km}$ and included a total of 10 camera traps with a 300-m separation between them (Figure 1A). Cameras were installed at a height of approximately $50 \mathrm{~cm}$ from the ground, slightly tilted downwards, and were set to take a sequence of five photographs per minute when motion was detected. A commercial cat bait made of seafood was used (Shellfish, Tomahawk Live Trap). Cameras remained active for three consecutive nights, representing an effort of 240 trap-nights in each biannual monitoring. The relative abundance index was calculated as the total number of visits (animals individually identified according to distinctive traits through photographs), divided by the total number of trap-nights.

According to Arnaud et al. (1994), cats are located mainly in the eastern area of the island; therefore, it was decided to concentrate the initial catch effort in that area. The control method consisted mainly in catching cats using leg-hold 
traps (Oneida Victor Soft Catch \#1 1/2) and lethal traps (Conibear Bodygrip Traps 10"), according to the experience in other islands in Mexico and worldwide (Rauzon 1985; Twyford et al. 2000; Phillips et al. 2005; Rodríguez et al. 2006; Rauzon et al. 2008; Luna-Mendoza et al. 2011). Leg-hold traps including pads were placed to fulfill good humanitarian practices (NOM033-ZOO-1995) in 220 sites (Figure 1B) over the duration of the expedition ( 21 to 51 days), and baited with a commercial cat bait made of seafood, tuna or fried sardine (Brothers 1982). Traps were reviewed daily from 7:00 to 10:00 h. Lethal and leghold traps located in hard-to-access sites were equipped with telemetry systems (ATS, mammal trap monitor Series M4000) to determine whether they had been activated from a distance (Will et al. 2010). Once cats were captured, these were euthanized by intramuscular injection of an anesthetic (Zoletil 50, Laboratories VIRBAC Mexico) and a lethal intracardiac injection (pentobarbitol), also following humanitarian euthanasia best practice guidelines (NOM-033-ZOO-1995). As a secondary method, night hunting was conducted using 0.222 caliber and 0.22 rifles with telescopic sights and lamps (Kohree 80,000 lux). The capture success was estimated with the formula $\mathrm{e}=$ (cats captured/trap-nights) x 100 .

Monitoring of native fauna. Since cats predate mainly on domestic mice, tree lizards and terrestrial birds (Arnaud et al. 1993; 1994), it was necessary to carry out a monitoring of the native species to determine and document any changes resulting from the control of the feral cat in Socorro Island. The Socorro Island tree lizard was monitored during April-May and October (two seasons per year) from 2012 to 2015. Twenty four transects were set (Aguirre-León 2011) in three different types
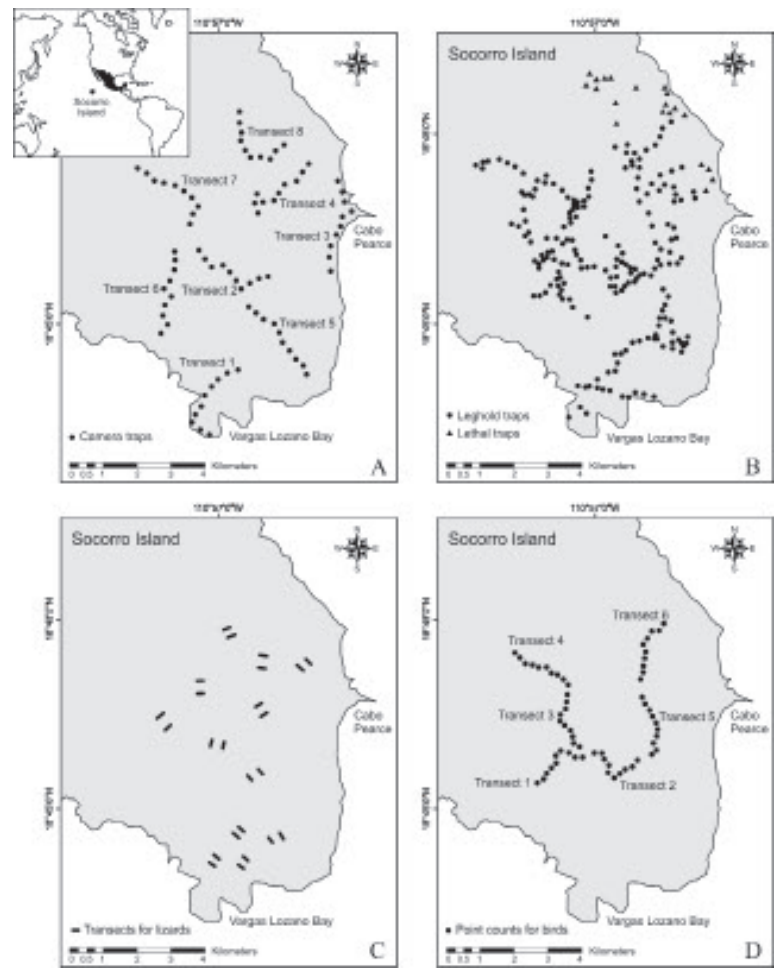

Figure 1. Location of A) transects of odor stations for monitoring feral cats through camera traps. B) Leg-hold trap (circles) and lethal traps (triangles) for the control of feral cats. C) transects for monitoring the Socorro Island tree lizard. D) Count-point transects for monitoring terrestrial birds. of habitat (eight transects per habitat type): forest, deciduous scrubland and eroded areas or areas impacted by sheep (devoid of vegetation, León de la Luz et al. 1994), each measuring $6 \mathrm{~m}$ wide by $100 \mathrm{~m}$ long (Figure 1C). Transects were visited during three consecutive days in each biannual monitoring, between 10:00 and 12:00 h. Density was estimated using the following formula: $\mathrm{D}=(n / 2 w L)$.

Where $n$ is the number of individuals counted, $L$ is total transect length, and $w$ is the width of the transect (Gallina and López-González 2011). A one-way repeated measures analysis of variance (rANOVA) was conducted to determine the effect of the season and habitat type on tree lizard density. The statistical software $R$ version 3.2.2 was used.

Terrestrial birds were monitored using the point-count technique (González-García 2011). Six transects were established in the island during April-May and October (two seasons per year) from 2012 to 2015 (Figure 1D). The monitoring was carried out from 6:30 to 9:30 $\mathrm{h}$ and was repeated on three consecutive days in each biannual season. At each site, all birds observed within a radius of $25 \mathrm{~m}$ during five minutes were counted. Subsequently, the observer moved to the next counting point located $250 \mathrm{~m}$ away, with a five-minute break before starting the next count. The statistical test rANOVA was run to determine the effect of season and habitat type on the total number of birds, plus Student $t$-tests for paired samples with a Bonferroni adjustment, to compare sightings during the different seasons.

\section{Results}

Feral cat monitoring and control. Camera trapping was used to determine the relative abundance of cats in the various zones of the eastern part of the island, as well as to guide capture efforts. In 2012, cats were found in all the sites studied; their abundance was higher toward the southeast (close to the Naval Sector), and lower in the northern zone and in the areas with the highest altitude (1,050 masl) in the central part of the island. As the cat control program progressed, the abundance of cats decreased drastically. By May 2015, cats were located only in transects recorded in the southernmost areas of the island (Figure 2). It was also noted that a lower number of cats in the entire island was observed as the monitoring seasons progressed. The success of cat capture during the trapping activities fluctuated throughout the year. However, a clear trend toward a smaller population was noted on a multi-year timescale (Figure 3). In general terms, the success of capture is greater in the dry season, and decreases during the rainy season (Table 1). Eight cats were dispatched by night hunting, to recover GPS collars; these specimens were not considered in the table of capture success.

Monitoring of native fauna. The results of tree lizard monitoring reveal that the population is increasing, considering both the dry and rainy seasons (Figure 4). Lizard density fluctuated significantly between seasons since the trapping of cats started in Socorro Island, $\mathrm{F}_{(6.12)}=4.4, p=0.014$. 


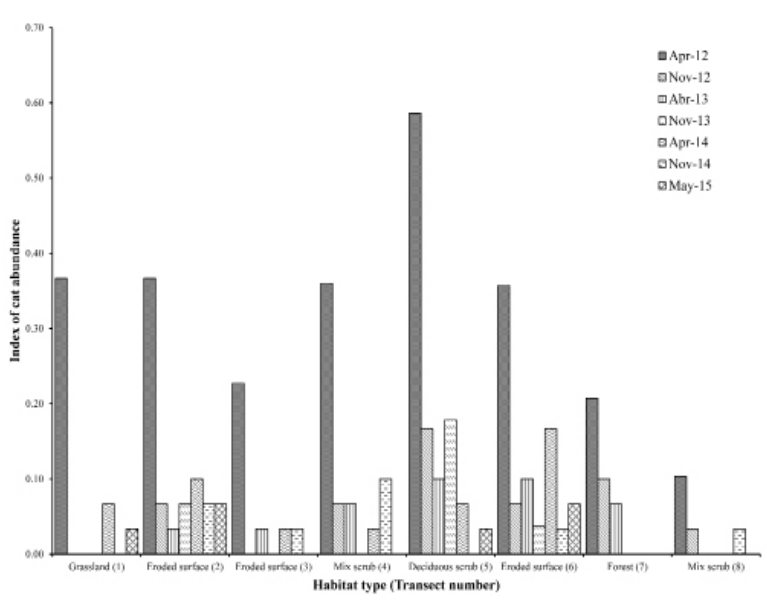

Figure 2. Relative abundance index of feral cats from 2012 to 2015 by vegetation type.

The number of birds sighted from 2012 to 2015 also showed significant differences between seasons, $F_{(5.96)}=5.36, P=2.2 \times$ $10^{-4}$. Although a population fluctuation is evident over the years of the study, there is an increase in the dry seasons of 2014 and 2015 (Table 2, Figure 5). Significant differences were found between November 2012 (study start-up and time point next to the eradication program start-up) and the rest of the monitoring monitoring times (except November 2014). No significant differences were found between dry seasons during the years 2013 to 2015. The most abundant species was the Socorro warbler (Setophaga pitiayumi graysoni), followed by the Socorro wren (Troglodytes sissonii), and the towhee (Pipilo maculatus socorrensis), all of them endemic to the island (Figure 5).

\section{Discussion}

A study to determine the home range of cats conducted in 2013 (Ortiz-Alcaraz, unpublished data), where necklaces fitted with GPS/VHF (Sirtrack Mod. G2C 128aWGPS 170 to $230 \mathrm{~mm}$ Necklace) were placed to six animals, revealed a mean home range of $2.19 \mathrm{~km}^{2}$ for males and $1.18 \mathrm{~km}^{2}$ for females. Based on this information and the experience in other Mexican islands (Luna-Mendoza et al. 2011), it was determined that traps should be separated by 300-500 meters to ensure that animals encounter at least one trap during their foraging movements.

Monitoring feral cat has served to adjust the trap-placement effort in the eastern part of the island, where they are most abundant (Arnaud et al. 1994). The trapping effort should

Table 1. Trap-nights, cats killed and capture success of feral cats in Socorro Island in the dry and rainy seasons from 2011 to 2015.

\begin{tabular}{rlrrr}
\hline Year & Season & Trap-nights & Cats killed & $\begin{array}{c}\text { Success of } \\
\text { capture }\end{array}$ \\
\hline 2011 & Rainy & 1,308 & 82 & 6.27 \\
2012 & Dry & 388 & 33 & 8.51 \\
& Rainy & 1,632 & 31 & 1.90 \\
2013 & Dry & 2,097 & 78 & 3.72 \\
& Rainy & 1,141 & 22 & 1.93 \\
2014 & Dry & 2,667 & 69 & 2.59 \\
& Rainy & 6,665 & 48 & 0.72 \\
& Dry & 5,080 & 43 & 0.85 \\
& Rainy & 1,728 & 7 & 0.41 \\
\hline \multirow{2}{*}{2015} & TOTAL & $\mathbf{2 2 , 7 0 6}$ & $\mathbf{4 1 3}$ & \\
\hline
\end{tabular}

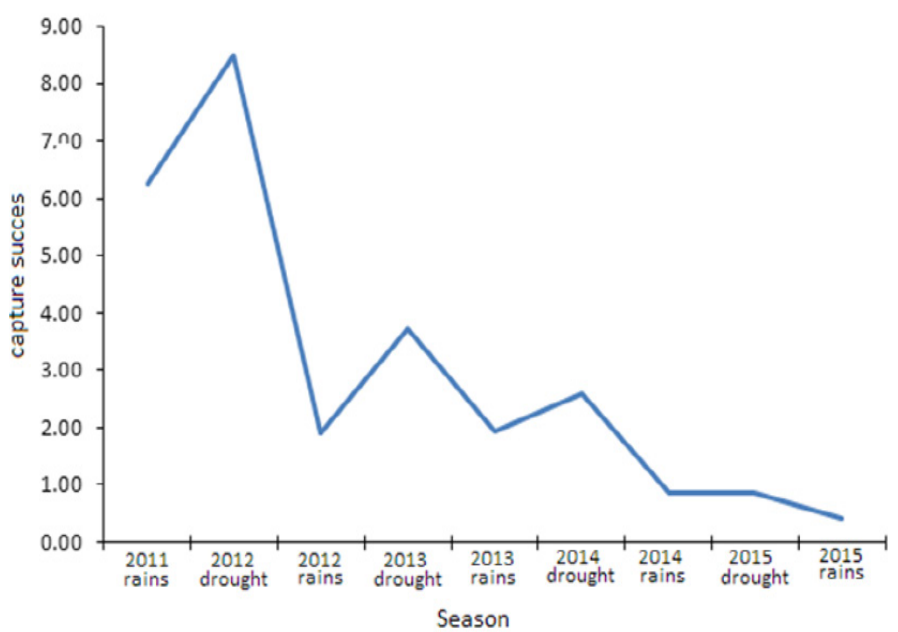

Figure 3. Reduction in the capture success (\%) of feral cats in the rainy and dry seasons from 2012 to 2015.

continue in order to catch the cats moving from one area to another. The capture of cats increases during the dry season (December to May) and decreases in the rainy season (June to November). These findings are not related to the abundance of cats, but are a sampling artifact, since moist land interferes with the installation of leg-hold traps, dry substrate to cover them is unavailable while rain compacts and hardens the substrate covering the traps impeding their activation. At the same time, another key factor that affects trapping in the rainy season is the higher abundance of land crabs (Gecarcinus planatus), which either consume the baits placed in traps or activate traps when attempting to reach the bait. Crabs are not caught in traps because they reach the bait from the back of the trap, but traps are nonetheless activated due to the crab's foraging activity. The combination of lethal traps and telemetry devices is essential during trapping in the most remote areas of the island. In this way, traps do not have to be checked daily but every five to seven days to replenish any bait lost to insects (mainly ants) and crabs (Parkes et al. 2012).

The Socorro Island tree lizard was found at higher densities in the deciduous scrubland, being less abundant in forests at higher altitudes. The results of this study show that the density of lizards in eroded surfaces was as high as 43 individuals/ha after cat was controlled, while Gallina-Tessaro et al. 1994 reported not having observed lizards in these areas. This may be due to a gradual recovery of the vegetation

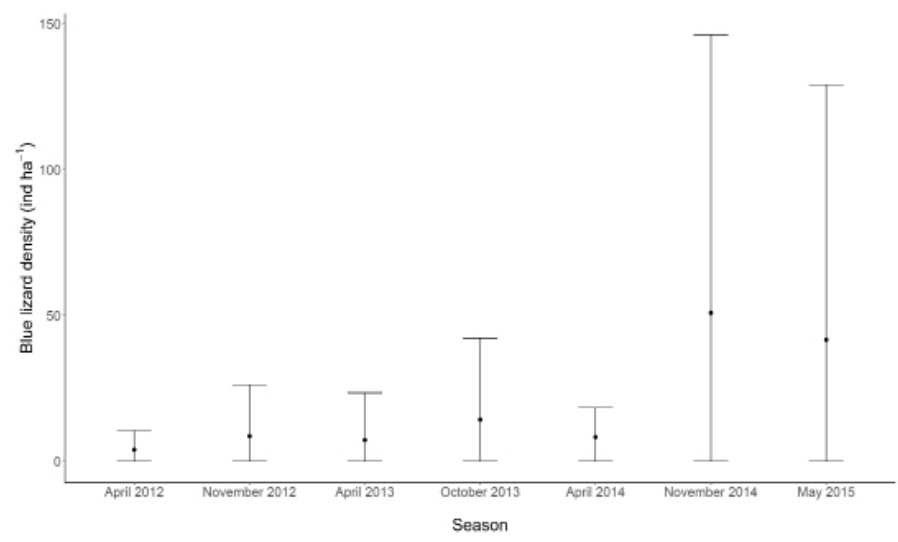

Figure 4. Mean density of the Socorro Island tree lizard (Urosaurus auriculatus), with confidence intervals, for the dry and rainy seasons from 2011 to 2015 in Socorro Island. 
Table 2. Sample size (N) of each season, average and standard deviation (SD) of the total number of birds for each season and its corresponding confidence interval $(\mathrm{Cl})$ for the average number of birds along 6 transects, with a confidence level of $95 \%$.

\begin{tabular}{rllrrc}
\hline Year & Season & N & Mean & \multicolumn{1}{c}{ SD } & CI \\
\hline 2012 & Rainy & 18 & 19.44 & 6.16 & $16.38-22.51$ \\
2013 & Dry & 18 & 38.56 & 14.16 & $31.51-45.60$ \\
& Rainy & 18 & 28.83 & 9.22 & $24.25-33.42$ \\
2014 & Dry & 18 & 52.00 & 19.87 & $42.12-61.88$ \\
& Rainy & 18 & 24.11 & 7.81 & $20.23-28.00$ \\
2015 & Dry & 18 & 50.89 & 31.01 & $35.47-66.31$ \\
\hline
\end{tabular}

resulting from the recent eradication of sheep (Ortiz-Alcaraz et al. 2016a; 2016b) and to the sustained trapping of cats in these areas. Lizard density was slightly higher during the rainy season, likely due to a higher food availability. As the cat control program in the eastern area of the island has progressed, the predation pressure of cats on the lizard population has decreased. Lizards are a major component of the cat's diet $(50 \%$ of fecal samples of cats analyzed contained lizard remains; Arnaud et al.1993).

The whighest number of birds was observed was the forest (Ficus - Guettarda - Ilex) vegetation type, especially in the highest parts of the island, where the recovery of vegetation resulting from the absence of grazing after sheep were eliminated has led to a greater availability of food and shelter against predators (Rodríguez-Estrella et al. 1994). Special efforts have been made to control cats in the forest, aiming to protect the native bird species such as the Townsend's shearwater (Ratcliffe et al. 2009). In 2015, a lower number of birds were watched relative to 2014 in eroded areas, Ficus (amate) forests and mixed shrubland. It is considered that the reduction is due to the visual interference of vegetation, as these areas had been previously eroded and subsequently colonized by shrub speceies such as Hyptis pectinata (up to $2.5 \mathrm{~m}$ height), Dodonaea viscose and the common fern (Pteridium caudatum). Additionally, to the above, cats are still present in these habitats, likely because of the considerable coverage provided by this type of vegetation. The eradication of feral cat and the monitoring of the native fauna should continue, in order to confirm recovery and to increase of the population size of the native fauna.

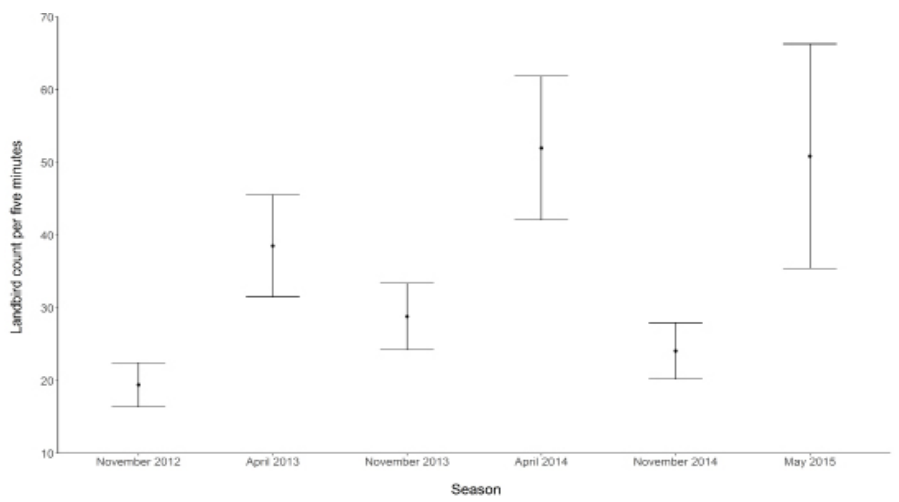

Figure 5. Average number of terrestrial birds with confidence intervals sighted during the dry and rainy seasons from 2012 to 2015 on Socorro Island.
The plans developed by Veitch (1989), Arnaud et al. (1993) and Parkes et al. (2012) agree in that feral cat can be eradicated using traditional techniques: trapping and night hunting. However, the experience in the island has highlighted the importance of using detection dogs to locate the remaining cats, either during the day, in their dens (providing an opportunity to set traps), or at night where cats may be killed by night hunting (Tortora 1982; Veitch 2001), as well as for the statistical confirmation of cat absence during the final stage of an eradication campaign (Ramsey et al. 2011).

As the eradication of feral cat in Socorro Island progresses, the populations of native vertebrates are recovering, as has happened in other islands (Rodriguez-Moreno et al. 2007; Aguirre-Muñoz et al. 2011). Once the absence of the cat in the island is confirmed statistically, the essential conditions for the successful reintroduction of the Socorro dove, a species currently extinct in the wild and preserved in captivity only — will be established (Yanga et al. 2011).

\section{Acknowledgments}

This study was developed in coordination with the Comisión Nacional de Áreas Naturales Protegidas (CONANP), with the invaluable support of Mexico's Secretariat of the Navy, Secretariat of the Environment and Natural Resources, and Secretariat of the Interior. Financial support was provided by the Alliance WWF -Fundación Carlos Slim, National Fish and Wildlife Foundation American Bird Conservancy, Packard Foundation, Marisla Foundation, in kind by SEMAR, as well as by GECl's own funds. The study was part of the activities developed by the Red Temática de Investigación Áreas Naturales Protegidas RENANP of CONACyT, project \# 269540, and the CONACYT Basic Science project \# 251919. We thank the Associate Editor C. Lorenzo Monterrubio, and two anonimous reviewers for their considerable time and effort in improving to a significant extent the first manuscript version. This manuscript was translated by María Elena SánchezSalazar with support of THERYA through a CONACYT grant.

\section{Literature cited}

Aguirre-León, G. 2011. Métodos de estimación, captura y contención de anfibios y reptiles. Pp. 48-65 in Manual de Técnicas para el estudio de la Fauna (Gallina, S., and C. López, eds.). Volumen I. Universidad Autónoma de QuerétaroInstituto Nacional de Ecología, A.C. Querétaro, Mexico.

Aguirre-Muñoz, A., A. Samaniego-Herrera, C. García-Gutiérrez, L. LunaMendoza, M. Rodriguez-Malagón, and F. Casillas-Figueroa. 2005. El control y la erradicación de fauna introducida como instrumento de restauración ambiental: historia, retos y avances en México. Pp. 215-230, in Temas sobre restauración ecológica (Sánchez, Ó., E. Peters, R. Márquez-Huitzil, E. Vega, G. Portales, M. Valdez, and D. Azuara, eds.). Instituto Nacional de Ecología. Ciudad de México, Mexico.

Aguirre-Muñoz, A., A. Samaniego-Herrera, L. Luna-Mendoza, A. Ortiz-Alcaraz, M. Rodriguez-Malagón, F. Méndez-Sánchez, M. FéliXLizárraga, J. C. Hernández-Montoya, R. González-Gómez, F. TorresGarcía, J. M. BarRedo-BARBerenA, AND M. LAtofski-Robles. 2011. Island restoration in Mexico: ecological outcomes after systematic 
eradications of invasive mammals. Pp. 250-258, in Island Invasives: Eradication and Management (Veitch, C. R., M. N. Clout, and D. R. Towns, eds.). Proceedings of the International Conference on Island Invasive. Occasional Paper of the IUCN Species Survival Commission No. 42. Gland, Suiza and Auckland, New Zealand.

Aguirre-Muñoz, A., A. Samaniego-Herrera, L. Luna-Mendoza, A. OrtizAlcaraz, F. Méndez-SáncheZ, and J. Hernández-Montoya. 2016. La restauración ambiental exitosa de las islas de México: una reflexión sobre los avances a la fecha y los retos por venir. Pp. 487-514, in Experiencias mexicanas en la restauración de los ecosistemas (Ceccon E., and C. Martínez-Garza, eds.). CRIMUNAM y CONABIO. Ciudad de México, Mexico.

Algar, D., C. J. Angus, R. I. Brazell, C. Gilbert, and D. J. Tonkin. 2004. Feral cats in paradise: Focus on Cocos. Atoll Research Bulletin 505:1-12.

Algar, D., G. J. Angus, R. I. Brazell, C. Gilbert, and G. B. Withnell. 2010. Eradication of feral cats on Faure Island, Western Australia. Journal of the Royal Society of Western Australia 93:133-140.

Álvarez-Cárdenas, S., A. Castellanos-Vera, P. Galina-Tessaro, and G. Arnaud. 1994. Aspectos de la población y el hábitat del borrego doméstico (Ovis aries). Pp. 301-317, in La Isla Socorro, Reserva de la Biosfera Archipiélago de Revillagigedo, México (Ortega-Rubio, A., and A. Castellanos-Vera, eds.). Centro de Investigaciones Biológicas del Noroeste, S. C. La Paz, Mexico. Arnaud, G., A. Rodríguez, A. Ortega-Rubio, and C. S. Álvarez. 1993. Predation by cats on the unique endemic lizard of Socorro Island (Urosaurus auriculatus), Revillagigedo, México. Ohio Journal of Science 93:101-104.

Arnaud, G., A. Rodríguez, and S. Álvarez. 1994. El gato doméstico (Felis catus), implicaciones de su presencia y alternativas para su erradicación. Pp. 341-359, in La Isla Socorro, Reserva de la Biosfera Archipiélago de Revillagigedo, México (Ortega-Rubio, A., and A. Castellanos-Vera, eds.). Centro de Investigaciones Biológicas del Noroeste, S. C. La Paz, Mexico.

Bester, M. N., J. P. Bloomer, R. J. Van Aarde, B. H. Erasmus, P. J. Van Rensburg, J. D. Skinner, P. G. Howell, and T. W. Naude. 2002. A review of the successful eradication of feral cats from sub-Antarctic Marion Island, Southern Indian Ocean. South African Journal of Wildlife Research 32:65-73.

Bonnaud, E., F. Medina, E. Vidal, M. Nogales, B. Tershy, E. Zavaleta, C. J. Donlan, B. Keitt, M. Le Corre, and S. V. Horwath. 2011. The diet of feral cats on islands: a review and a call for more studies. Biological Invasions 13:581-603.

Brattstrom, B. H. 2015. Food Webs and Feeding Habits on the Revillagigedo Islands, Mexico. Pacific Science 69:181-195.

Brothers, N. P. 1982. Feral cat control on Tasman Island. Australian Ranger Bulletin 2:9.

Comisión Nacional de Áreas Naturales Protegidas (CONANP). 2004. Programa de conservación y manejo Reserva de la Biosfera Archipiélago de Revillagigedo. CONANP-SEMARNAT. Ciudad de México, Mexico.

Chapuis, J. L., P. Boussès, And G. Barnaud. 1994. Alien mammals, impact and management in the French subantarctic islands. Biological Conservation 67:97-104.

DiAmond, J. M. 1989. Overview of recent extinctions. Pp 37-41, in Conservation for the twenty-first century (Western, D., and M.C. Pearl, eds.). Oxford University Press. New York, USA.
Donlan, C. J., B. R. Tershy, K. J. Campbell, and F. CRUz. 2003. Research for requiems: the need for more collaborative action in eradication of invasive species. Conservation Biology 17:1-2. Dowding, J. E., E. C. Murphy, K. Springer, A. J. Peacock, and C. J. KREBS. 2009. Cats, rabbits, myxoma virus, and vegetation on Macquarie Island: a comment on Bergstrom et al. (2009). Journal of Ecology 46:1129-1132.

EBENHARD, T. 1988. Introduced birds and mammals and their ecological effects. Swedish Wildlife Research 13:1-107.

Galina-Tessaro, P., S. Alvarez-Cárdenas, and A. Ortega. 1994. Aspectos ecológicos de la Herpetofauna. Pp. 185-197 in La Isla Socorro, Reserva de la Biósfera Archipiélago de Revillagigedo, México (Ortega-Rubio, A., and A. CastellanosVera eds.). Centro de Investigaciones Biológicas del Noroeste, S. C. La Paz, México.

GallinA, S., AND C. LóPEZ-GonzÁlez (eds). 2011. Manual de técnicas para el estudio de la fauna. Volumen I. Universidad Autónoma de Querétaro-Instituto de Ecología A. C. Querétaro, Mexico.

GonzÁlez-García, F. 2011. Métodos para contar aves terrestres. Pp. 128-147 in Manual de técnicas para el estudio de la fauna Volumen I (Gallina, S., and C. López-González eds.). Universidad Autónoma de Querétaro-Instituto Nacional de Ecología, A. C. Querétaro, Mexico.

GroombridGe, B. E. 1992. Global Diversity-Status of the Earth's Living Resources. Compiled by the World Conservation Monitoring Center. Chapman \& Hall. London, United Kingdom.

Hernández-Montoya, J. C., L. Luna-Mendoza, A. Aguirre-Muñoz, F. Méndez-Sánchez, M. Félix-Lizárraga, and J. M. BarredoBarberenA. 2014. Laysan Albatross on Guadalupe Island, México: current status and conservation actions. Monographs of the Western North American Naturalist 7:543-554.

Johnson, T. H., And A. J. Stattersfield. 1990. A Global Review of Island Endemic Birds. The Ibis 132:167-180.

Jones, H. P., N. D. Holmes, S. H. M. Butchart, B. R. Tershy, P. J. Kappes, I. Corkery, A. Aguirre-Muñoz, D. P. Armstrong, E. Bonnaud, A. A. Burbidge, K. Campbell, F. Courchamp, P. E. Cowan, R. J. Cuthbert, S. Ebbert, P. Genovesi, G. R. Howald, B. S. Keitt, S. W. Kress, C. M. Miskelly, S. Oppel, S. Poncet, M. J. Rauzon, G. Rocamora, J. C. Russell, A. SamaniegoHerrera, P. J. Seddon, D. R. Spatz, D. R. Towns, and D. A. Croll. 2016. Invasive mammal eradication on islands results in substantial conservation gains. Proceedings of the National Academy of Sciences 113:4033-4038.

León de la Luz, J. L., A. BreCeda, R. CoriA-Benet, And J. Cancino-Hernández. 1994. Asociaciones vegetales. Pp. 115-141, in La Isla Socorro, Reserva de la Biosfera Archipiélago de Revillagigedo, México (Ortega-Rubio, A., and A. Castellanos-Vera, eds.). Centro de Investigaciones Biológicas del Noroeste, S. C. La Paz, Mexico.

Levin, J. A., And R. Moran. 1989. The vascular flora of Isla Socorro, México. San Diego Society of Natural History University of Michigan. San Diego, U. S. A.

Luna-Mendoza, L., J. M. Barredo-Barberena, J. C. Hernández-Montoya, A. Aguirre-Muñoz, F. Méndez-Sánchez, A. Ortiz-Alcaraz, and M. FéliXLIZÁRRAGA. 2011. Planning for the eradication of feral cats on Guadalupe Island, México: home range, diet, and bait acceptance. Pp. 192-197 in Island Invasives: Eradication and Management (Veitch, C. R., M. N. Clout, and D. R. Towns, eds.). Proceedings of the International Conference on Island Invasives. Occasional Paper of the IUCN Species Survival Commission No. 42. Gland, Switzerland and Auckland, New Zealand. 
Martínez-Gómez, J. E., A. Flores-Palacios, and R. L. Curry. 2001. Habitat requirements of the Socorro Mockingbird Mimodes graysoni. Ibis 143:456-467.

Martínez-Gómez, J. E., and J. Jacobsen. 2004. The Conservation Status of Townsend's Shearwater Puffinus auricularis. Biological Conservation 116:35-47.

Maya-Delgado, Y., F. Salinas-Zavala, and E. Troyo-Diéguez. 1994. Estado actual del suelo y propuestas para su conservación. Pp. 63-75 in La Isla Socorro, Reserva de la Biosfera Archipiélago de Revillagigedo, México (Ortega-Rubio, A., and A. Castellanos-Vera, eds.). Centro de Investigaciones Biológicas del Noroeste, S. C. La Paz, Mexico.

Moro, D. 1997. Removal of a feral cat from Serrurier Island. The Western Australian Naturalist 21:153-156.

Ortiz-Alcaraz, A., A. Aguirre-Muñoz, F. Méndez-Sánchez, and A. OrTEgA-RuBIO. 2016a. Feral sheep eradication at Socorro Island, Mexico: A mandatory step to ensure ecological restoration. Interciencia 41:184-189.

Ortiz-Alcaraz, A., Y. Maya-Delgado, P. Cortés-Calva, A. Aguirre-Muñoz, E. Rojas-Mayoral, M. Cordoba-Matson, and A. Ortega-Rubio. $2016 \mathrm{~b}$. Recovery of Vegetation Cover and Soil after the Removal of Sheep in Socorro Island, Mexico. Forests 7:91.

Parkes, J., P. Fisher, and S. Robinson. 2012. Eradication of feral cats on large Mexican Islands: a discussion of options and feasibility. Lincoln, New Zealand: Invasive Species International, Landcare Research New Zealand.

Parkes, J., P. Fisher, S. Robinson, And A. Aguirre-Muñoz. 2014. Eradication of feral cats from large islands: an assessment of the effort required for success. New Zealand Journal of Ecology 38:307-314.

Phillips, R. B., B. D. Cooke, K. Campbell, V. Carrion, C. Marquez, and H. L. SNell. 2005. Eradicating feral cats to protect Galápagos land iguanas: methods and strategies. Pacific Conservation Biology 11:57-66.

Ramsey, D. S. L., J. P. Parkes, D. Will, C. C. Hanson, and K. J. Campbell. 2011. Quantifying the success of feral cat eradication, San Nicolas Island, California. New Zealand Journal of Ecology 35:163-173.

Ratcliffe, N., M. Bell, T. Pelembe, D. Boyle, R. Benjamin, R. White, B. Godley, J. SteVenson, And S. SAnders. 2009. The eradication of feral cats from Ascension Island and its subsequent recolonization by seabirds. Oryx 44:20-29.

RAUZON, M. J. 1985. Feral cats on Jarvis Island: their effects and their eradication. Atoll Research Bulletin 282:1-30.

Rauzon, M. J., W. T. Everett, D. Boyle, L. Bell, and J. Gilardi. 2008. Eradication of feral cats at Wake Atoll. Atoll Research Bulletin 560:1-21.

Rodríguez-Estrella, R., L. Rivera, and E. Mata. 1994. Avifauna terrestre. Pp. 199-224 in La Isla Socorro, Reserva de la Biosfera Archipiélago de Revillagigedo, México (Ortega-Rubio, A., and A. Castellanos-Vera, eds.). Centro de Investigaciones Biológicas del Noroeste, S. C. La Paz, Mexico.

Rodríguez, C., R. Torres, AND H. Drummond. 2006. Eradicating introduced mammals from a forested tropical island. Biological Conservation 130:98-105.

Rodríguez-Moreno, A., G. Arnaud, And B. Tershy. 2007. Impacto de la erradicación del gato (Felis catus), en dos roedores endémicos de la isla Coronados, Golfo de California, México.
Acta Zoológica Mexicana (n. s.) 23:1-13.

TORTORA, D. F. 1982. Understanding electronic dog-training.1. Canine Practice 9:17-22.

Twyford, K. L., P. G. Humphrey, R. P. NunN, ANd L. Willoughby. 2000. Eradication of feral cats (Felis catus) from Gabo Island, southeast Victoria. Ecological Management and Restoration 1:4249.

VeITCH, C. R. 1989. The eradication of cats and sheep from Socorro Island: A report to the Socorro Island project. Northern region technical report series. Department of Ccnservation. Auckland, Nueva Zelanda.

VEITCH, C. R. 2001. The eradication of feral cats (Felis catus) from Little Barrier Island, New Zealand. New Zealand Journal of Zoology 28:1-12.

Veitch, C. R., and M. N. Clout (eds.). 2002. Turning the Tide: The Eradication of Invasive Species. Proceedings of the International Conference on Eradication of Island Invasives. Occasional Paper of the IUCN Species Survival Commission No. 27. Gland, Switzerland.

Veitch, C. R., M. N. Clout, and D. R. Towns (eds.). 2011. Island Invasives: Eradication and Management. Proceedings of the International Conference on Island Invasives. Gland, Switzerland and Auckland, New Zealand.

Will, D., C. C. Hanson, K. J. Campbell, D. K. Garcelon, and B. S. Keitt. 2010. A trap monitoring system to enhance efficiency of feral cat eradication and minimize adverse effects on non-target endemic species on San Nicolas Island. Proceedings of the Vertebrate Pest Conference 24:79-85.

Wood, B., B. R. Tershy, M. A. Hermosillo, C. J. Donlan, J. A. Sánchez, B. S. Keitt, D. A. Croll, G. R. Howard, and N. Biavaschi. 2002. Removing cats from islands in north-west Mexico. Pp. 374380 in Turning the tide: the eradication of invasive species (Veitch, C. R., and M. N. Clout, eds.). IUCN SSC Invasive Species Specialist Group. Gland, Switzerland an Cambridge, United Kingdom.

Yanga, S., J. Martínez-Gómez, R. Sehgal, P. Escalante, F. Camacho, AND D. BELL. 2011. A preliminary survey for avian pathogens in Columbiform birds on Socorro Island, Mexico. Pacific Conservation Biology 17:11-20.

Associated editor: Consuelo Lorenzo

Submitted: June 22, 2016; Reviewed: August 29, 2016;

Accepted:September 1, 2016; Published on line: November 20, 2016 
10 THERYA Vol. 8(1):3-9 